2cta 3ivlogica Gibirica

Journal of Biology

Founded in 2015
Altai State University

www.asu.ru

ISSN 2412-1908

Acta Biologica Sibirica, 2017, 3(3), 57-65

\title{
Phytoplankton of the Boguchany reservoir in 2016-2017 at the stations in front of the hydroelectric dam
}

\author{
M.V. Usoltseva, L.A. Titova \\ Limnological Institute of the Siberian Branch \\ of the Russian Academy of Sciences, Irkutsk, Russia \\ usmarina@inbox.ru, titova873@mail.ru
}

\begin{abstract}
The species structure and seasonal dynamics of the phytoplankton of the dam area of the Boguchany Reservoir were studied in the first years of operation of the hydroelectric power station in 2016-2017. Two peaks of algal bloom are noted in spring and summer. Mass species were: diatom Stephanodiscus minutulus and dinophyte Gymnodinium baicalense in spring; diatoms Asterionella formosa and Fragilaria crotonensis, blue-green Dolichospermum lemmermannii, D. flosaquae, D. flosaquae f. spiroides and Aphanizomenon flosaquae; green Sphaerocystis planctonica and dinophyte Ceratium hirundinella in summer; diatoms F. crotonensis and A. formosa, cryptophytic Rhodomonas pusilla and Cryptomonas ovata in autumn. The cryptophyte $R$. pusilla and the Cryptomonas species were dominated under the ice. The maximum number of phytoplankton (9 million cells in liter) was recorded in the spring. According to the indixes of saprobity, the purity of water corresponded to II-III quality classes (pure and moderately polluted water).

Key words: Angara River; Boguchany Dam; phytoplankton; diatoms; biomass
\end{abstract}

\section{Фитопланктон приплотинного участка Богучанского водохранилища в 2016-2017 гг.}

\author{
М.В. Усольцева, Л.А. Титова \\ Лимнологический институт Сибирского отделения Российской академии наук, \\ Иркутск, Россия \\ usmarina@inbox.ru, titova_873@mail.ru
}

\begin{abstract}
Исследована видовая структура и сезонная динамика фитопланктона приплотинного участка Богучанского водохранилища в первые годы работы ГЭС в 2016-2017 гг. Отмечено 2 пика цветения водорослей - весной и летом. Массовыми видами были: весной - диатомовая Stephanodiscus minutulus и динофитовая Gymnodinium baicalense; летом - диатомовые Asterionella formosa и Fragilaria crotonensis, синезеленые Dolichospermum lemmermannii, D. flosaquae, D. flosaquae f. spiroides и Aphanizomenon flosaquae; зеленая Sphaerocystis planctonica и динофитовая Ceratium hirundinella; осенью - диатомовые F. crotonensis и A. formosa, криптофитовые Rhodomonas pusilla и Cryptomonas ovata. В подледный период доминировали криптофитовые R. pиsilla и виды
\end{abstract}


Usoltseva, M.V., Titiva, L.A. (2017). Phytoplankton of the Boguchany.... Acta Biologica Sibirica, 2017, 3(3), 57-65

Cryptomonas. Максимальная численность фитопланктона (9 млн кл./л.) отмечена весной. Согласно индексам сапробности, чистота воды соответствовала II-III классам качества (воды чистые и умеренно загрязненные).

Ключевые слова: река Ангара; Богучанская ГЭС; фитопланктон; диатомовые; биомасса

\section{Введение}

Река Ангара представляет собой могучий сибирский водный поток, вытекающий из Байкала и впадающий в р. Енисей. С учётом того, что Байкал является горным озером, река по своему течению имеет большой перепад высот, который составляет 380 м. Это указывает на значительный энергетический потенциал, который благоприятен для создания гидроэлектростанций (ГЭС) (http://www.factruz.ru/world ocean/angara-river.htm).

На сегодняшний день на Ангаре располагается каскад водохранилищ, в состав которого входят 4 гэС: Иркутская, Братская, Усть-Илимская и Богучанская. Богучанское водохранилище стало четвертой, нижней, ступенью Ангарского каскада ГЭС. Строительство Богучанского гидроузла было начато в 1980 г. и после длительного перерыва возобновлено в 2006 г. Наполнение водохранилища началось в мае 2012 г., а первые три агрегата введены в эксплуатацию в ноябре 2012 г. В июне 2015 г. Богучанское водохранилище было впервые заполнено до проектной отметки 208 м, а в июле станция вышла на проектный уровень производства. Завершение строительства и ввод в промышленную эксплуатацию Богучанской гЭС планируется на декабрь 2017г.

Создание водохранилищ влечет за собой изменение среды обитания для биоты реки, в первую очередь фитопланктона - первичного звена пищевой цепи. Условия среды обитания могут меняться и формироваться в течение нескольких лет, поэтому необходим регулярный мониторинг за состоянием гидробионтов и, фитопланктона, в том числе. Ранее проводились многолетние исследования фитопланктона Иркутского (Vasil'eva, Kozhova, 1960, 1963; Kozhova, 1964), Братского (Kozhova, 1975; Vorob'eva, 1981 b), Усть-Илимского водохранилищ (Vorob'eva, 1987, 1988) и участка реки Ангары в районе Богучанского водохранилища (Vorob'eva, 1986; Sheveleva, Vorob'eva, 2009). Обобщающие сведения приведены в работах (Kozhova, 1978; Kozhova, Basharova, 1984; Vorob'eva, 1981 а, 1985, 1995). На основании этих исследований был сделан прогноз (Sheveleva, Vorob'eva, 2009), согласно которому в условиях зарегулирования в Богучанском водохранилище возрастут видовое разнообразие и количественные показатели фитопланктона, а основу биомассы составят диатомовые водоросли родов Stephanodiscus Ehrenberg, Aulacoseira Thwaites, Tabellaria Ehrenberg ex Kützing, Fragilaria Lyngbye, Asterionella Hassall, при значительном развитии криптофитовых (Rhodomonas G. Karsten, Cryptomonas Ehrenberg) и синезеленых водорослей (Aphanizomenon A. Morren ex É. Bornet et C. Flahault, Anabaena Bory ex Bornet et Flahault (=Dolichospermum (Ralfs ex Bornet et Flahault) P.Wacklin, L. Hoffmann et J. Komárek)). Было высказано мнение, что невысокая проточность водоема обусловит массовое развитие в теплый период синезеленых водорослей, что может отразиться на качестве воды (Sheveleva, Vorob'eva, 2009).

Целью данной работы является представление данных о видовом составе и сезонной динамике фитопланктона приплотинной части Богучанского водохранилища в первые годы работы ГЭС.

\section{Материалы и методы исследований}

Материалом для исследований послужили пробы фитопланктона, отобранные поздней весной (май-июнь), летом (июль), осенью (октябрь) 2016 г. и ранней весной в ледовый период (март) 2017 г. Пробы отбирали в приплотинном участке Богучанской ГЭС (500 м до плотины) на трех станциях (рис. 1) с поверхностного слоя воды (0 M).

Количественные пробы отбирали с помощью батометра. Фиксацию проб проводили раствором Люголя с ацетатом натрия по общепринятой методике (Sadchikov, 2003). Для количественного учета фитопланктона пробы концентрировали с помощью осадочного метода (Kiselev, 1969; Guide to hydrobiological monitoring..., 1992). Подсчет клеток водорослей проводили по методу Гензена (Kiselev, 1969) на разграфленном тонком предметном стекле в капле, взятой штемпель-пипеткой объемом 0,1 мл в двух-кратной повторности с помощью светового микроскопа «Axiovert 200» ZEISS (Германия) с фотокамерой Pixera Penguin 600CL. Биомассу клеток определяли расчетным способом (Makarova, Pichkily, 1970; Belykh et al., 2011). Оценку сапробного состояния воды рассчитывали по методу Пантле и Букка (Pantle, Buck, 1955) в модификации Сладечека (Sladecek, 1977; Sladecek et al., 1981). Индикаторные значения видов учитывали согласно опубликованной методике (Barinova, Medvedeva, Anisimova, 2006). Идентификацию мелкоклеточных центричных диатомовых проводили с помощью сканирующего электронного микроскопа (СЭМ) Philips SEM 525М (Голландия), для этого использовали собранный во время экспедиции нефиксированный материал, осажденный на фильтры «Whatman» с диаметром 13 мм и с диаметром пор 1 мкм. После высушивания на воздухе фильтры приклеивали на столики для СЭМ, напыляли золотом и анализировали на базе ЦКП «Электронная микроскопия» Объединенного ЦКП «Ультрамикроанализ» Лимнологического института СО РАН. 


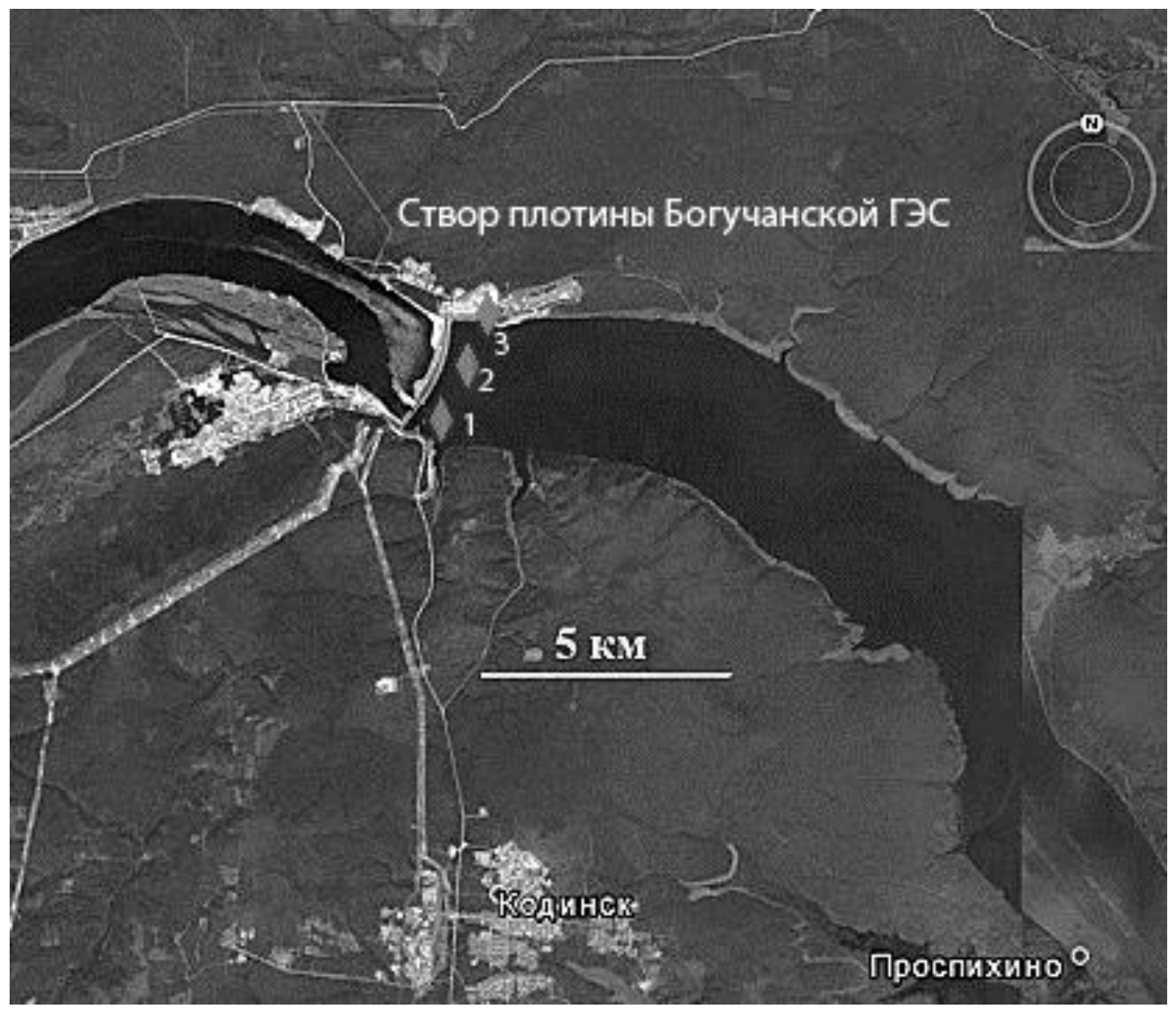

Рис. 1. Станции отбора проб в приплотинной части Богучанского водохранилища.

1 - 50 м от левого берега, 2 -центр, 3 - 50 м от правого берега

\section{Результаты}

В результате исследования сезонной динамики фитопланктона поверхностного слоя в приплотинном участке Богучанского водохранилища показано, что общая численность и биомасса фитопланктона варьирует по сезонам. Выделено 2 пика развития водорослей - весной и летом (рис. 2). Максимальная численность (6,4-9 млн кл./л) отмечена весной. Летом она была ниже и составляла 2,2-3,7 млн кл./л. Биомасса при этом была в 3 раза больше летом, чем весной, и варьировала в пределах 4,8-6,4 г/м³. В октябре и марте численность и биомасса водорослей были значительно ниже и составляли 45-114 тыс. кл./л; 77-190 мг/м³ и 43-90,5 тыс. кл./л; 109-336 мг/м³ соответственно.

Всего в приплотинном участке Богучанского водохранилища за период исследований фитопланктона обнаружено 25 видов и внутривидовых таксонов, относящихся к диатомовым, динофитовым, криптофитовым, зеленым, синезеленым и хризофитовым водорослям (табл. 1).

Из всего многообразия видов можно выделить 10-15, которые вносили значимый вклад в численность и биомассу фитопланктона (рис. 3, 4). Абсолютным доминантом по численности (рис. 3, 5) в мае-июне был S. minutulus, на его долю приходилось более 95\% от общей численности фитопланктона. Это - мелкоклеточный вид, поэтому, несмотря на высокую численность, из-за мелких размеров клеток, на его долю приходилось 20-28 \% от общей биомассы фитопланктона (рис. 4). Основной вклад (65-76 \% от общей биомассы фитопланктона) в этот период вносил крупноклеточный вид G. baicalense.

Летом доминирующими по численности были F. crotonensis, S. planctonica, A. formosa, A. flosaquae и виды рода Dolichospermum (рис. 3, 5). Основной вклад в биомассу вносили крупноклеточные виды C. hirundinella, F. crotonensis и A. formosa (рис. 4). 


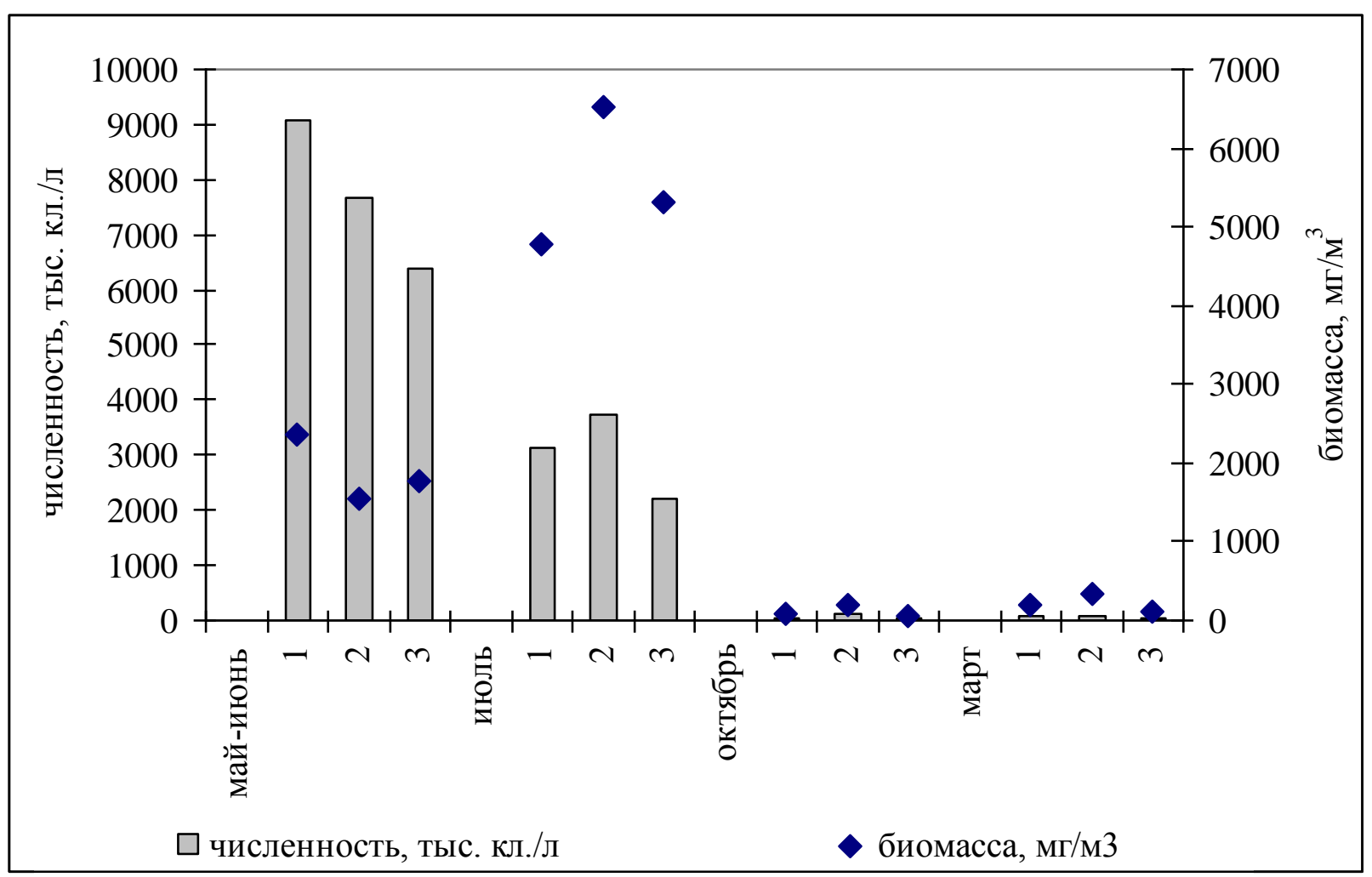

Рис. 2. Общая численность и биомасса фитопланктона приплотинного участка Богучанского водохранилища.

1 - 50 м от левого берега, 2 - центральная станция, 3 - 50 м от правого берега

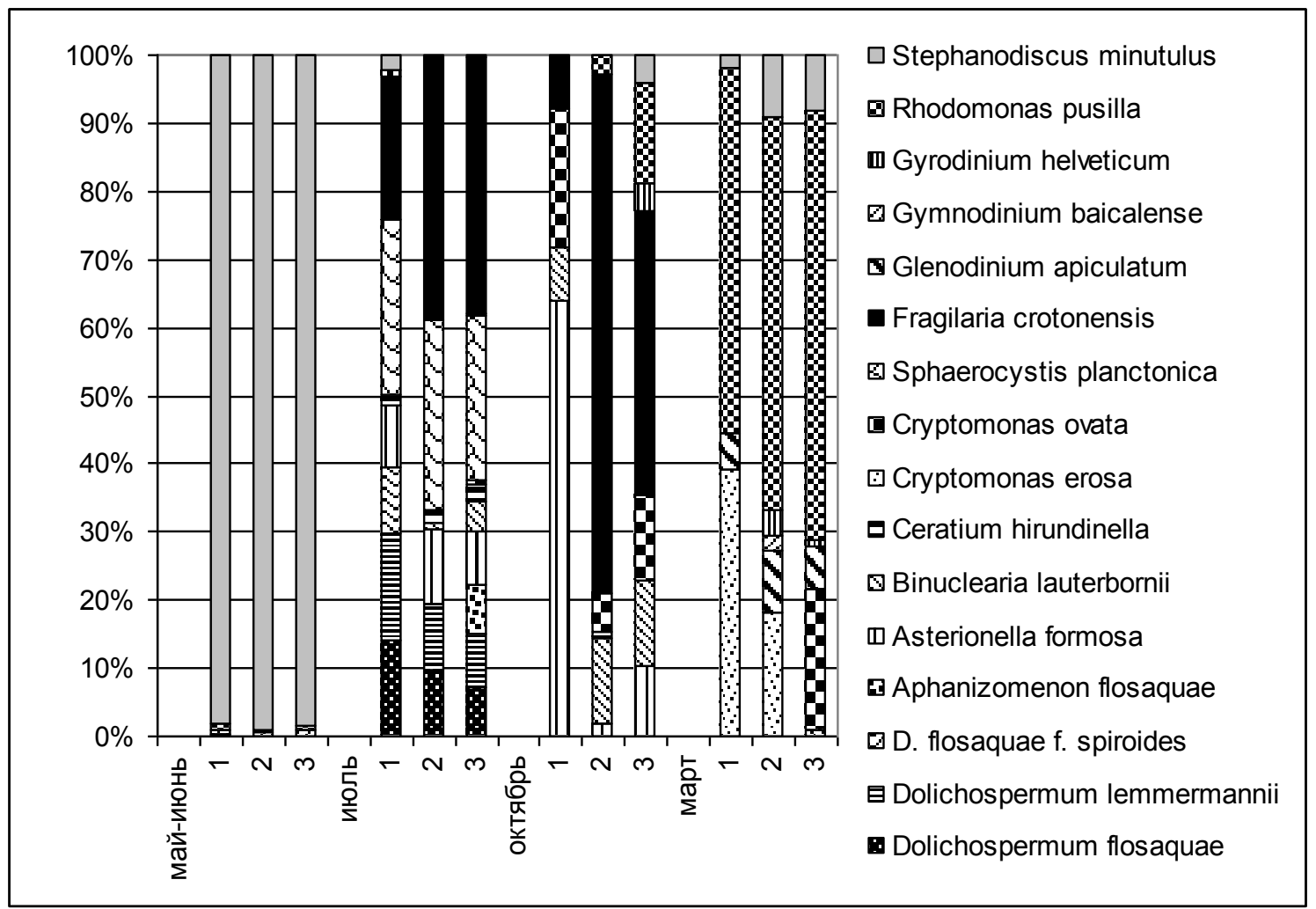

Рис. 3. Процентное соотношение видов фитопланктона приплотинного участка Богучанского водохранилища по численности в разные сезоны года 
Таблица 1. Видовой состав фитопланктона в разные сезоны в приплотинном участке Богучанского водохранилища в 2016-2017 гг. 1 - 50 м от левого берега, 2 - центральная станция, 3 - 50 м от правого берега

Виды

\section{Диатомовые водоросли}

Asterionella formosa Hassall

Aulacoseira islandica (O. Müller) Simonsen

Fragilaria crotonensis Kitton

Stephanodiscus minutulus (Kützing) Cleve et Möller Tabellaria fenestrata (Lyngbye) Kützing

Cyclotella baicalensis Skvortzow

\section{Динофитовые}

Ceratium hirundinella (O.F. Müller) Dujardin

Glenodinium apiculatum Ehrenberg

Gymnodinium baicalense Antipova

Gyrodinium helveticum (Penard) Y.Takano et

T.Horiguchi

\section{Криптофитовые}

Cryptomonas ovata Ehrenberg

Cryptomonas erosa Ehrenberg

Rhodomonas pusilla (H.Bachmann) Javornicky

\section{Зеленые водоросли}

Binuclearia lauterbornii (Schmidle) Proschkina-

Lavrenko

Cosmarium praemorsum Brébisson

Elakatothrix gelatinosa Wille

Sphaerocystis planctonica (Korshikov) Bourrelly

Staurastrum anatinum Cooke et Wills

Staurastrum lunatum Ralfs

\section{Синезеленые водоросли}

Aphanizomenon flosaquae Ralfs ex Bornet et

Flahault

Dolichospermum lemmermannii (Richter) P.Wacklin,

L.Hoffmann et J.Komárek

Dolichospermum flosaquae (Brébisson ex Bornet et

Flahault) P.Wacklin, L.Hoffmann et J.Komárek

Dolichospermum flosaquae f. spiroides (Bornet \&

Flahault) Woronichin

\section{Золотистые водоросли}

Dinobryon divergens O.E.Imhof

Mallomonas acaroides Perty
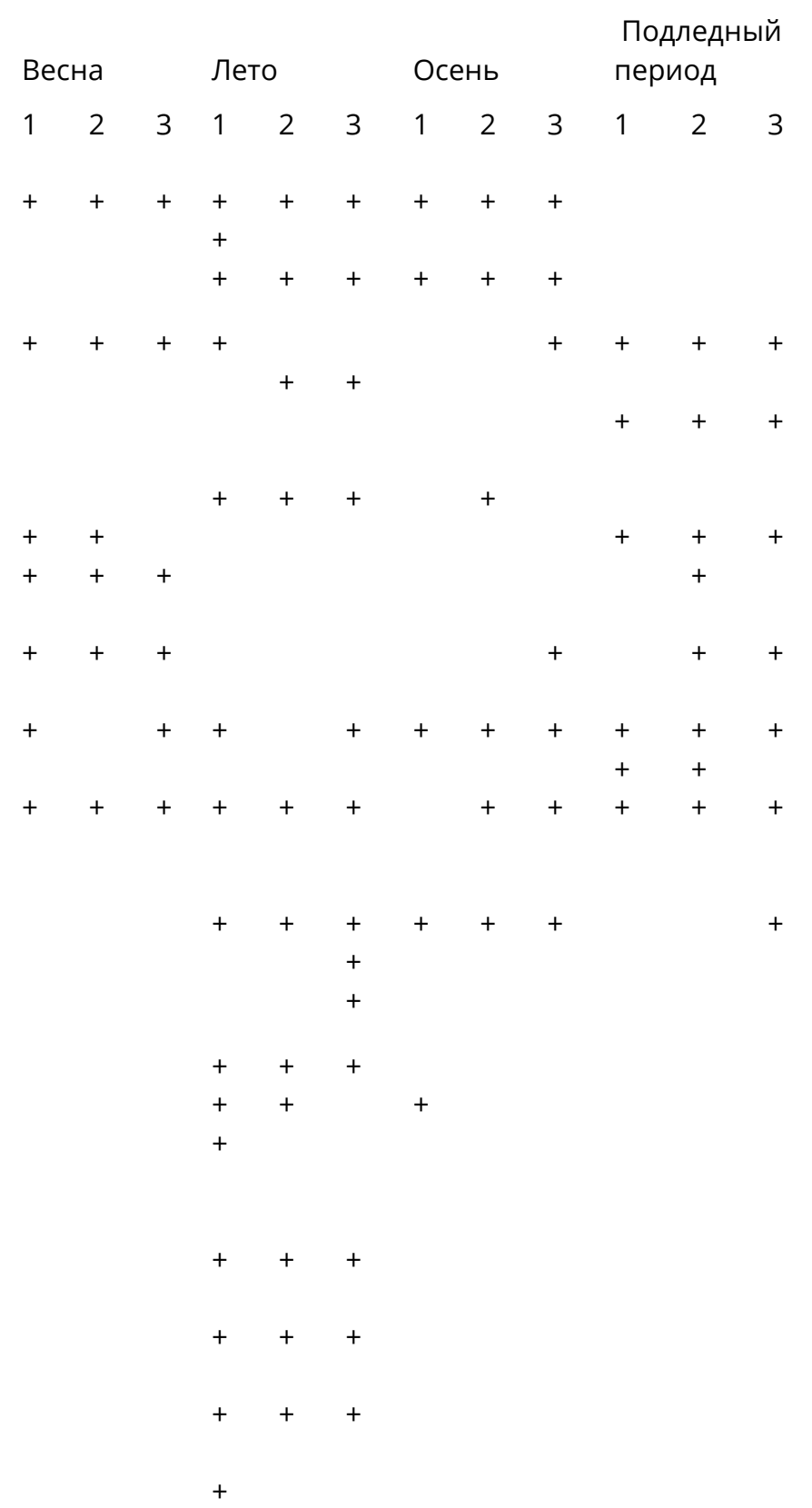

Осенью по численности доминировали A. formosa и F. crotonensis. Им сопутствовали C. ovata, B. lauterbornii и R. pusilla (рис. 3, 5). Основной вклад в биомассу вносили C. hirundinella, F. crotonensis, A. formosa и G. apiculatum (рис. 4).

Видовой состав водорослей подледного фитопланктона был беден (рис. 5), в небольших количествах встречались S. minutulus (рис. 5), C. baicalensis, R. pusilla, G. baicalense, G. helveticum и Gl. apiculatum. Доминантом по численности в поверхностном слое в это время был мелкоклеточный вид R. pusilla (рис. 3), на долю которого приходилось около 60 \% от общей численности и 5-8 \% от общей биомассы фитопланктона (рис. 4). Основной вклад в биомассу вносили крупноклеточные виды Gl. apiculatum, G. baicalense, G. helveticum, C. erosa и C. ovata (рис. 4). 


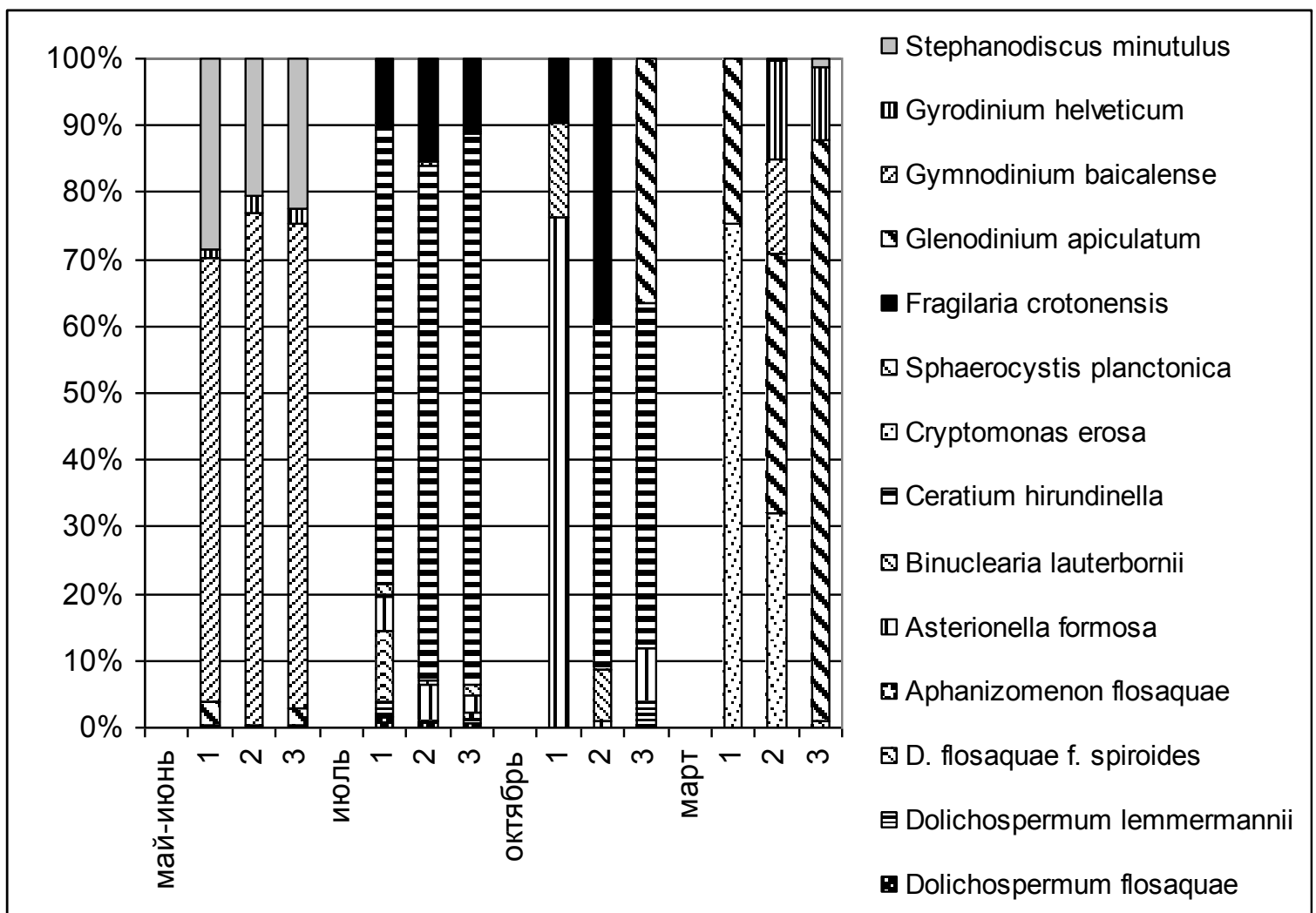

Рис. 4. Процентное соотношение видов фитопланктона приплотинного участка Богучанского водохранилища по биомассе в разные сезоны года

Для оценки экологического состояния приплотинного участка Богучанского водохранилища и контроля качества воды рассчитана сапробность для каждого сезона (табл. 2). Минимальные значения отмечены в маеиюне, а максимальные в июле-октябре. Согласно индексам сапробности, чистота воды соответствует II-III классам качества (воды чистые и умеренно загрязненные).

Таблица 2. Индексы сапробности в приплотинном участке Богучанского водохранилища в разные сезоны года

\begin{tabular}{lll} 
Сезон & Сапробность & Класс чистоты воды \\
май-июнь 2016 г. & $1,36-1,40$ & II \\
июль 2016 г. & $1,87-2,05$ & III \\
октябрь 2016 г. & $2,0-2,26$ & III \\
март 2017 г. & $1,53-1,75$ & III \\
\hline
\end{tabular}

\section{Обсуждение}

Зарегулирование стока в результате создания Богучанской ГЭС привело к изменению морфометрических, гидрологических, гидрохимических характеристик реки Ангары - сформировался новый водоем - Богучанское водохранилище. Наши данные являются базовыми показателями состояния фитопланктона приплотинного участка Богучанского водохранилища на момент его формирования.

Сравнение с данными о состоянии фитопланктона до зарегулирования на этом участке Ангары показало, что, хотя основной комплекс доминирующих видов остался прежним, как и до зарегулирования, фитопланктон претерпевает трансформации в связи с изменением условий среды обитания.

Во-первых, несколько изменяется видовая структура. Если до создания Богучанской ГЭС, кроме основного комплекса видов в реке развивались виды Diatoma vulgare Bory, $\quad$ T. fenestrata и Aulacoseira granulata (Ehrenberg) Simonsen (Vorob'eva, 1995), то после зарегулирования $T$. fenestrata встречалась в небольших количествах, а $A$. granulata и D. vulgare вообще не обнаружены. Известно, что последний вид предпочитает участки с повышенными скоростями течения. В массе он развивался на участке Ангары до зарегулирования стока Усть-Илимского водохранилища (Vorob'eva, 1995). A. granulata в исследуемый нами период не встретилась, хотя часто развивалась в массе в теплое время года в выше расположенных водохранилищах Усть-Илимском и Братском, достигая численности (2,9 и 3,6млн кл./л) (Vorob'eva, 1995). Впервые для Богучанского водохранилища отмечено появление и высокое развитие вида Sphaerocystis planctonica. Максимальные его концентрации (0,67 и 2,2 млн кл./л) также отмечались ранее (Vorobyeva, 1995) для выше расположенных водохранилищ - Усть-Илимского и Братского. 
Usoltseva, M.V., Titiva, L.A. (2017). Phytoplankton of the Boguchany.... Acta Biologica Sibirica, 2017, 3(3), 57-65

Во-вторых, произошло увеличение численности некоторых доминирующих видов. По сравнению с максимальным развитием фитопланктона речного участка реки Ангары в районе приплотинного участка Богучанского водохранилища в 1984 г. (Vorob'eva, 1995), численность S. minutulus в 2016 г. стала в 2,4 раза больше, D. lemmermannii - в 2,8 раз, а F. crotonensis - в 9,4 раз. Численность F. crotonensis достигала значений, характерных для Усть-Илимского водохранилища, где ее численность в многолетнем аспекте (1972-1987 гг.) варьировала от 0,02 до 14, 1 млн кл./л. В то же время, в 1975, 1978, 1979, 1981, 1983 гг. она составляла 1,1-1,6 млн кл./л, что сопоставимо с данными 2016 г.

Сравнение общей численности и биомассы фитопланктона в приплотинном участке до и после зарегулирования ГЭС отражено в таблице 3.

Таблица 3. Сравнение численности и биомассы фитопланктона до и после зарегулирования Богучанской ГЭС

\begin{tabular}{|c|c|c|c|c|}
\hline \multirow[b]{2}{*}{ Сезон } & \multicolumn{2}{|c|}{1984 г. (Воробьева, 1995) } & \multicolumn{2}{|c|}{ 2016-2017 г. (наст. данные) } \\
\hline & $\begin{array}{l}\text { численность, } \\
\text { тыс. кл./л }\end{array}$ & 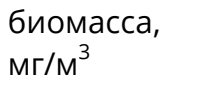 & $\begin{array}{l}\text { численность, } \\
\text { тыс. кл./л }\end{array}$ & $\begin{array}{l}\text { биомасса, } \\
\text { мг/м }{ }^{3}\end{array}$ \\
\hline поздняя весна & 2006 & 665 & $6400-9000$ & $1500-2400$ \\
\hline лето & 1597 & 318 & $2200-3700$ & $4800-6400$ \\
\hline осень & 318 & 174 & $45-114$ & $77-190$ \\
\hline подледный & нет данных & нет данных & $43-90,5$ & $109-336$ \\
\hline период & & & & \\
\hline
\end{tabular}

Из таблицы 3 следует, что численность и биомасса фитопланктона поздней весной и летом 2016 г. были значительно выше, чем в 1984 г. Численность фитопланктона осенью 1984 г. была выше, чем в 2016 г., а биомасса сопоставима (174 и 190 мг/м³). Эти данные уже сейчас частично подтверждают прогноз (Vorobyeva, 1995; Sheveleva, Vorobyeva, 2009), согласно которому, в условиях зарегулирования возрастут количественные показатели. Авторами было высказано опасение, о том, что невысокая проточность водоема обусловит массовое развитие в теплый период синезеленых водорослей, что может отразиться на качестве воды. Для оценки качества воды в 2016-17 гг. произведен расчет индексов сапробности проб в приплотинном участке водохранилища. Индекс сапробности изменялся в интервале 1,36-2,26, что соответствовало II-ІІІ классам качества (воды чистые и умеренно загрязненные). Этот показатель в районе речного участка будущего Богучанского водохранилища в разные годы (1977-2007 гг.) и сезоны варьировал в пределах 1,46-3,11, что соответствовало II-IV классам чистоты вод (Sheveleva, Vorobyova, 2009). Соответственно, изменения качества воды пока не наблюдается.

Полученные данные являются базовыми показателями состояния фитопланктона приплотинного участка Богучанского водохранилища, с которыми можно будет проводить сравнение последующих изменений фитопланктона. Формирование флоры будет происходить определённый период, и количественные показатели фитопланктона тоже будут меняться. Вовремя заметить и оценить степень этих изменений позволит регулярный мониторинг за состоянием этой новой экосистемы.

\section{Благодарности}

Авторы выражают благодарность ПАО «Богучанская ГЭС» в лице генерального директора В.В. Демченко за предоставленную возможность проведения исследований по оценке фонового состояния водохранилища на договорных условиях, К.Ю. Арсентьеву и И.С. Михайлову за отбор проб фитопланктона, С.С. Воробьевой, В.В. Минаеву и анонимным рецензентам журнала за ценные замечания и рекомендации. Работа выполнена в рамках бюджетной темы ЛИН СО РАН № 0345-2016-0001 и договора № 769/2016. Микроскопические исследования проведены в ЦКП «Электронная микроскопия» Объединенного ЦКП «Ультрамикроанализ» ЛИН СО РАН.

\section{References}

Angara River. Available from: http://www.factruz.ru/world ocean/angara-river.htm. Accessed on 25.09.2017

Barinova, S.S., Medvedeva, L.A., Anisimova, O.V. (2006). Bioraznoobrazie vodoroslej indikatorov okruzhayushchej sredy. TelAviv, Pilies Studio. (in Russian)

Belykh, O.I., Bessudova, A.Yu., Gladkih, A.S., Kuz'mina, A.E., Pomazkina, G.V., Popovskaya, G.I., Sorokovikova, E.G., Tihonova, I.V., Usol'ceva, M.V., Firsova, A.D. (2011). Rukovodstvo po opredeleniyu biomassy vidov fitoplanktona pelagiali ozera Bajkal: metod. posobie. Ye.V. Likhoshway (Ed.). Irkutsk, Izd-vo IGU. (in Russian)

Kiselev, I.A. (1969). Plankton morej i kontinental'nyh vodoemov, 1. Vvodnye i obshchie voprosy planktonologii, Leningrad, Nauka. (in Russian)

Kozhova, O.M. (1964). Fitoplankton Irkutskogo vodohranilishcha. Biologiya Irkutskogo vodohranilishcha. Moscow, Nauka. (in Russian) 
Usoltseva, M.V., Titiva, L.A. (2017). Phytoplankton of the Boguchany.... Acta Biologica Sibirica, 2017, 3(3), 57-65

Kozhova, O.M. (1975). Vodoobmen i intensivnost' vegetacii fitoplanktona Bratskogo vodohranilishcha. Krugovorot veshchestva i ehnergii v ozernyh vodoemah. Novosibirsk, Nauka. (in Russian)

Kozhova, O.M. (1978). Nekotorye osobennosti formirovaniya fitoplanktona vodohranilishch. Vodnye Resursy, 3, 94106. (in Russian)

Kozhova, O.M., Basharova, N.I. (1984). Produktivnost' angarskih vodohranilishch. Biologicheskie resursy vnutrennih vodoemov Sibiri i Dal'nego Vostoka. Moscow, Nauka. (in Russian)

Makarova, I.V., Pichkily, L.O. (1970). K nekotorym voprosam metodiki vychisleniya biomassy fitoplanktona. Botanicheskij Zhurnal, 55 (10), 1488-1494. (in Russian)

Pantle, R., Buck, H. (1955) Die Biologische Uberwahund der Gewasser und Darstellung Ergebnisse. Gas-und Wasserfach., 96.

Rukovodstvo po gidrobiologicheskomu monitoringu presnovodnyh ehkosistem. (1992). V.A. Abakumov (Ed.). SanktPeterburg: Gidrometeoizdat. (in Russian)

Sadchikov, A.P. (2003). Metody izucheniya presnovodnogo fitoplanktona: metodicheskoe rukovodstvo. Moscow, "Universitet i shkola". (in Russian)

Sheveleva, N.G., Vorob'eva, S.S. (2009). Sostoyanie i razvitie fito- i zooplanktona nizhnego uchastka Angary, prognoz formirovaniya planktona v Boguchanskom vodohranilishche. Journal of Sibirian Federal University, 313-326. (in Russian)

Sladecek, V. System of water quality from biological point of view. (1973). Arch. Hydrobiol, Stuttgart.

Sládeček, V., Zelinka, M., Rothschein, J., Moravcová, V. Biologický rozbor povrchové vody. Komentář k ČSN 830532 části 6: Stanoveni saprobniho indexu. (1981). Vydalo Vydavatelstvi Üřadu pro normalizaci a měřeni, Praha. (in Czech)

Vasil'eva, G.L., Kozhova, O.M. (1960). Nekotorye dannye o bakterio-, fito- i zooplanktone Irkutskogo vodohranilishcha v gody ego obrazovaniya (1957-1958 gg.). Byul. Instituta Biologii Vodohranilishch, 8-9, 6-8. (in Russian)

Vasil'eva, G.L., Kozhova, O.M. (1963). Plankton Irkutskogo vodohranilishcha. Trudi VGBO, 13, 25-52. (in Russian)

Vorob'eva, S.S. (1981a). Fitoplankton angarskih vodohranilishch. Krugovorot veshchestva i ehnergii v vodoemah, 1, 5052. (in Russian)

Vorob'eva, S.S. (1981b). Fitoplankton. Plankton Bratskogo vodohranilishcha. Novosibirsk, Nauka. (in Russian)

Vorob'eva, S.S. (1985). Mezhgodovye izmeneniya fitoplanktona angarskih vodohranilishch. Krugovorot veshchestva i ehnergii v vodoemah, 2, 20-22. (in Russian)

Vorob'eva, S.S. (1986). Vodorosli reki Angary v zone Boguchanskogo vodohranilishcha. Botanika, fiziologiya i biohimiya rastenij, kormoproizvodstvo, 42-44. (in Russian)

Vorob'eva, S.S. (1987). Fitoplankton. Biologiya Ust'-Ilimskogo vodohranilishcha. Novosibirsk, Nauka. (in Russian)

Vorob'eva, S.S. (1988). Sostav, dinamika i osobennosti formirovaniya fitoplanktona Ust'-llimskogo vodohranilishcha. Problemy ehkologii Pribajkal'ya, 2. Irkutsk, IGU. (in Russian)

Vorob'eva, S.S. (1995). Fitoplankton vodoemov Angary. Novosibirsk, Nauka. (in Russian)

\section{Citation:}

Usoltseva, M.V., Titiva, L.A. (2017). Phytoplankton of the Boguchany reservoir in 2016-2017 at the stations in front of the hydroelectric dam. Acta Biologica Sibirica, 3 (3), 57-65.

Submitted: 03.07.2016. Accepted: 04.09.2017

crossref http://dx.doi.org/10.14258/abs.v3i3.3616

(C) 2017 by the authors. Submitted for possible open access publication under the terms and conditions of the Creative Commons Attribution (CC BY) license (http://creativecommons.org/licenses/by/4.0/). 